\title{
LA MÚSICA CEREMONIAL MEXICA
}

\section{THE MEXICA CEREMONIAL MUSIC}

\author{
José Antonio Guzmán Bravo \\ Facultad de Música, UNAM (México) \\ santris2005@yahoo.com.mx \\ ORCID iD: https://0000-0001-9084-8280
}

\begin{abstract}
Resumen
El artículo trata de la relación de música y sociedad en el contexto cultural mexica, las escuelas de enseñanza y la organización del servicio ritual de los templos, los cargos y diferencias de maestros que tenían para la instrucción de los jóvenes que se dedicaban al servicio de ellos. Las danzas dedicadas a deidades específicas, según los dictados del Calendario Ceremonial (Cempoalapohualli), la predestinación para la música, cifrada en el Calendario Adivinatorio (Tonalpohualli), los servicios prestados por los jóvenes a los templos (velar, coger leña, mantener los fuegos rituales y los cantos y bailes adecuados para cada momento litúrgico). El uso ritual de alucinógenos. Y los instrumentos musicales prehispánicos.
\end{abstract}

\section{Palabras clave}

Música mexica, instrumentos, calendario ritual, escuelas de música, deidades musicales, códices, deberes del servicio ritual, uso ritual de alucinógenos.

\section{LA MÚSICA CEREMONIAL MEXICA}

\section{MÚSICA Y SOCIEDAD}

La nación azteca o mexica ${ }^{1}$, como ellos se nombraban en los primeros años del siglo XVI, había logrado construir, en el seno de la magnífica urbe de México-Tenochtitlan, el centro ceremonial más importante del Nuevo Mundo. Poblada de suntuosos templos y palacios, canales de acceso y comunicación, amplísimas plazas, puentes y calzadas, mobiliario, esculturas, murales, objetos preciados de culto, la ciudad albergaba además centros de educación, templos especializados en el servicio a

1 Mexicatl: s. Mexicano, habitante de México; pl. mexica; rev. mexicatzintli; R. Mexico. Simeón, Remi, (1977).

(C) 2018 CSIC. Este es un artículo de acceso abierto distribuido bajo los términos de una licencia de uso y distribución Creative Commons Attribution 4.0 International (CC BY 4.0)

Cómo citar este artículo/Citation: Guzmán Bravo, J. A. (2018). La música ceremonial mexica. Anuario Musical, 73: 37-52. doi: http://dx.doi.org/10.3989/redc.2018.73.03

\begin{abstract}
The article deals with the relation of music and society in the Mexica cultural context, the ritual schools to teach and organize the temple's services, as well as with the diverse types of teachers and types of instruction given at the temples. The dances dedicated to specific deities as prescribed by the Ceremonial Calendar ( $\mathrm{Cem}$ poalapohualli), predestination for musical destiny as given by the Divinatory Calendar (Tonalpohualli), and the personal services given by the young people to the temples: watch over night, gather firewood, keep the bonfires, perform the different dances and songs as prescribed by the liturgy. The ritual use of hallucinogenic plants. And the prehispanic musical instruments.
\end{abstract}

\section{Key words}

Mexica (aztec) music, Musical instruments, Ritual calendar, Music schools, Musical deities, Codex representations, Ritual service duties, Use of hallucinogenic plants.

dioses particulares, con sus rituales apropiados, cámaras dónde se guardaban los libros de pictogramas o códices, los atavíos indispensables para las representaciones rituales de dioses y una sala en particular para la custodia, culto, restauración y conservación de los instrumentos musicales llamada Mixcoacalli².

"Había otra sala que se llamaba Mixcoacalli. En este lugar se juntaban todos los cantores de México y Tlatelulco, aguardando a lo que les mandase el señor, si quisiese bailar o probar o oír algunos cantares de nuevo compuestos. Y tenían a la mano aparejados todos los atavíos del areito, atambor y tamboril, con sus instrumentos para tañer el atambor, $\mathrm{y}$ unas sonajas que se llaman ayacachtli y tetzilácatl y 
Omichicahuaztli y flautas, con todos los maestros tañedores y cantores y bailadores, y los atavíos del areito para cualquier cantar"'.

El Mixcoacalli de Tenochtitlan era el lugar donde se guardaban todos los implementos para los cantos y danzas; Sahagún señala que este recinto guardaba los teponaztlis y sus baquetas con punta de hule (olmaitl), el huéhuetl, las sonajas en forma de adormideras, ayacachtli, las campanas de cobre, tetzilácatl, las flautas pentáfonas pareadas, çoçoloctli, los omichicahuaztli o raspadores de hueso, y se reunían todos los ejecutantes o tañedores de teponaztli, los teponaçoani; de huéhuetl, huehuetzoani, quienes entonaban el canto y llevaban las danzas $C u$ Icaitoani-Teiacanque.

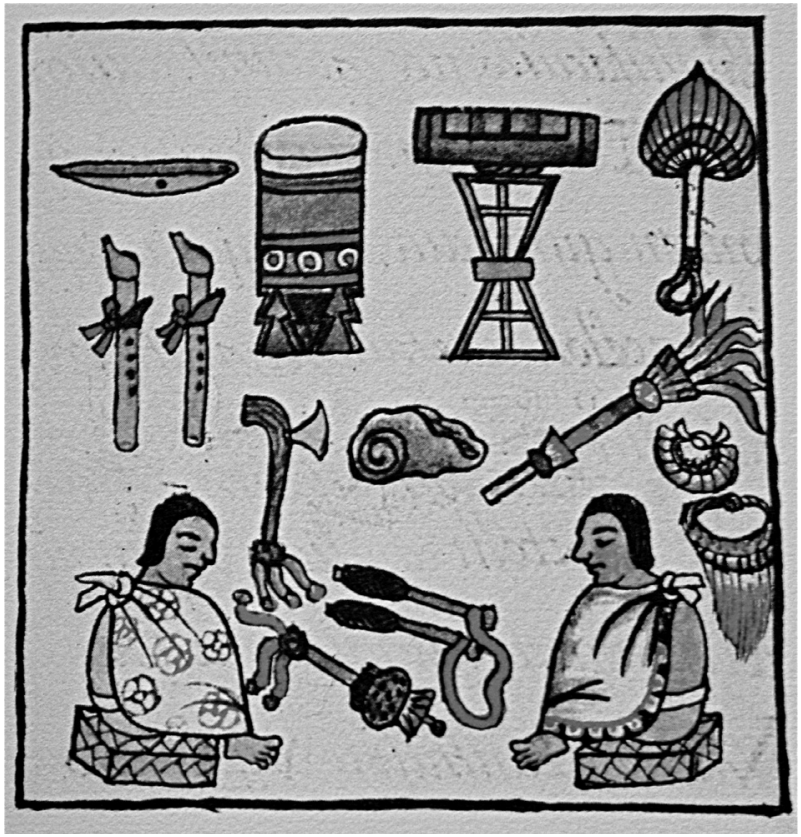

Ilustración 1, Sala del Mixcoacalli: Dos custodios músicos, Tetzilácatl (concha de metal tipo gong percutida), Huéhuetl (tambor trípode de membrana), Teponaztle (tamboril horizontal idiófono, percutido con baquetas con punta de ulli, (caucho, goma), 2 Çololoctli (flautas pentáfonas), Tecciztli (trompeta de caracol), Ayacachtlis (sonajas), sartales, abanico y atavíos sonoros ${ }^{4}$.

El desarrollo de la danza, la música y el canto, por la urgencia de una urbe rica y poblada, generó escuelas rituales controladas por los sacerdotes que agrupaban músicos, poetas, cantores y bailarines; todos ellos, cabe decir la palabra, profesionales, estimulados por las jerarquías civiles y religiosas. Esta

3 SAHAGÚN (1982): T.II, Lib. VIII, Cap. XIV, 7, 397.

4 SAHAGÚN (1982): T.II, Libro VIII, 384. organización musical sobrevivió parcialmente a la conquista española, tomando cuerpo en cofradías de rezanderos, fiscales o cantores que hasta la fecha representan la participación de la comunidad en los asuntos rituales muchas veces sin la participación de la clerecía oficial de la Iglesia. Los cuicapicque, compositores de cantos, residentes en los templos de la nueva fe, mantenían algunos privilegios y mercedes todavía a fines del siglo XVI. En esta época los señores indios conservaban aún el uso de maestros de capilla a su servicio.

El rasgo más característico de la política musical azteca fue la creación de una casta de artistas al servicio de los templos y palacios, con privilegios civiles, como la exención de tributos de la cual gozaban los músicos profesionales.

Los señores de México-Tenochtitlan celebraban a los artistas músicos y danzantes el día 1-Flor; Ce Xóchitl, fecha institucionalizada para fiestas que a veces duraban todo un mes según parecer del señor.

"Y la señal de que había de mandar él a la gente que bailara, era poner enhiestos dos palos enflorados: se colocaban en el palacio, en la casa real. Con ellos se daba a conocer que era fiesta de flores, de alegrarse con flores, de gozar con flores" .

En esta ocasión se premiaba a los cantores, compositores, tañedores, a los que silbaban o danzaban, a los cantores brujos. El gusto musical, manifiesto en el aprecio que tenían señores y vasallos por ciertos ejecutantes, valoraba artistas de talento excepcional cuya fama era conocida. Fue célebre en la corte mexica Quecholcohuatzin, quien en el año 13-Caña, (1479), cuando los mexicanos conquistaron Taxco, fue a cantar, junto con los de Amecameca y Chalco, a la ciudad de México-Tenochtitlán ante el señor Axayacatzico, el cual gustó tanto del canto, que era llamado "La Enemiga”, que él mismo se incorporó a la danza. El señor de México hizo que Quecholcohuatzin permaneciera en su palacio como su cantor personal, otorgándole grandes honores y riquezas “ premió al Quecholcohuatzin, pues le había complacido extremadamente que lo hubiera hecho danzar, y precisamente a causa de su gran ardor en la música quiso el Axayacatzin que solamente él, en lo adelante, condujese los conciertos para que no se volviera a dar el caso de que alguien desmereciese su canto" este canto era propiedad del noble Quiyauhzin Cuaunquiyauhcatzintli, poeta y compositor es decir, cantor:

El referido señor Axayacatzin, con frecuencia hizo que lo cantaran en sus residencias y palacios y en cada vez se entusiasmaba y emocionaba grandemente. Siempre quien dirigía el canto era aquel antes dicho, Quecholcohuatzin... Este mismo canto lo dejó en herencia, el Axayacatzin a su hijo querido, el nombrado Tezozomoctli Acolnahuacatl, y éste a su vez, a su hijo, nieto de Axayacatzin, el que se llamó

5 GARIBAY (1953): 164, trad, del Manuscrito Palatino, fol. 201. 6 CHIMALPAIN (1966): 211. 
don Diego de Alvarado Huanitzin, quien fue nombrado señor de Ehecatépec y que después vino a ejercer como gobernador de México-Tenochtitlan, todos los cuales jefes también hicieron conciertos con este canto y bailaron danzas ceremoniales a sus ritmos en sus casas palaciegas de México, a causa de que era una maravilla este cantar, y que gracias a él la ciudad de Amaquemecan tuvo gloria y fama.

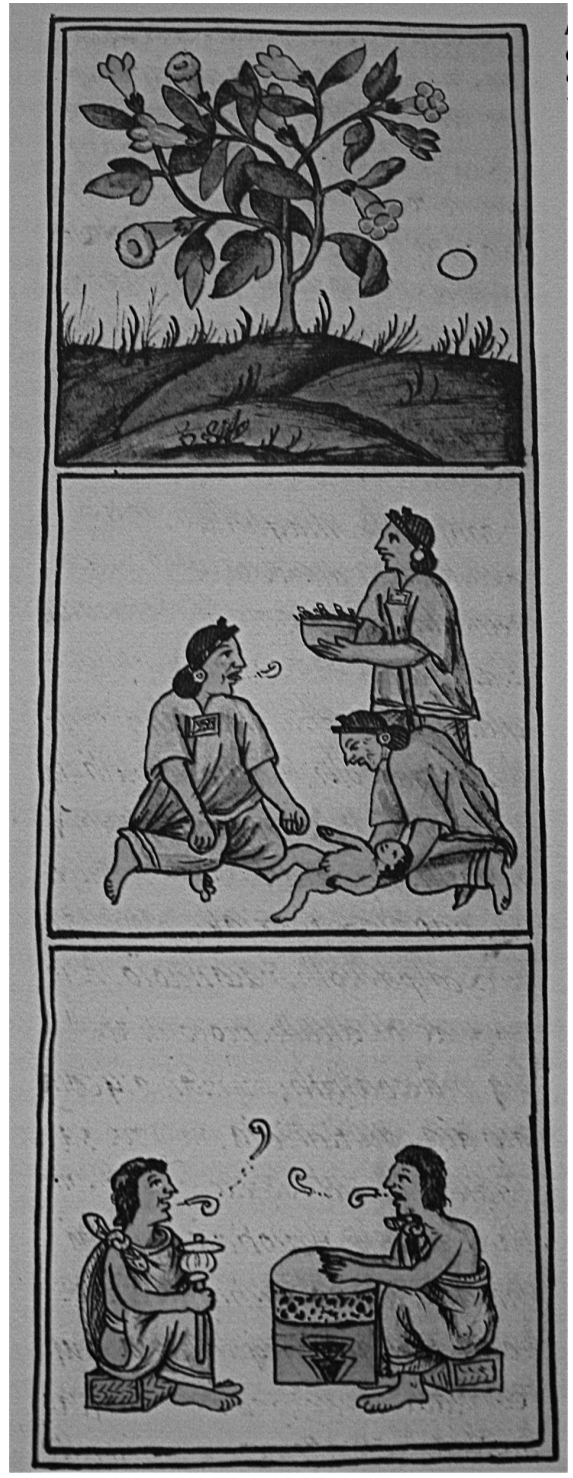

Ilustración 2, Signo del día uno flor (Ce Xóchitl), bautizo a un recién nacido en el signo, celebración cantada ${ }^{8}$.

7 CHIMALPAIN (1966): 211.

8 SAHAGÚN (1982): I, 176.
Un análisis musicológico del ritual mexica no puede prescindir de la noción original de integridad que se observa en el arte prehispánico: la música, la danza y la poesía fueron considerados como un todo dentro de la práctica azteca. No menos cierto es el considerar este ritual en el espacio sagrado de plazas y templos como parte de una liturgia mayor, que incluía sacrificios, penitencias, ofrendas, ingestión de alucinógenos, teonanácat ${ }^{9}$, péyotl y otros tipos de hierbas y semillas, que tenían por objeto estimular la percepción de los sentidos: se afinaba la música hacia la trascendencia de la realidad cotidiana. Este perfil de estimulación al público participante con psicodislépticos ha sido poco estudiada y resulta ingrediente imprescindible para comprender la inducción al éxtasis y a estados de conciencia que creaban una compenetración íntima colectiva y una percepción magnificada del ritual.

El celo por la perfección interpretativa entre los mexicas los llevaba a recurrir al castigo corporal e incluso a la pena de muerte para aquellos cantores o tañedores y danzantes que equivocaban el texto, la melodía o el paso, ya que comprometiendo la integridad y perfección del rito se afectaba su eficacia.

Los artistas, aun cuando recibiesen honores y riquezas formaban parte del servicio doméstico de palacios y templos. Los músicos eminentes recibían un mécatl o cordel distintivo que colgaban del cuello, bajando en dos puntas decoradas encima del pecho con un colgante de caracol, concha o caparazón de tortuga. Podían cantar, bailar y hablar en distintos estilos según el origen de las ceremonias, danzas o cantares; de Huejotzingo, del Anáhuac, de la Huasteca, etc.

Las deidades del panteón mexica mantenían sus servicios musicales particulares, pero dioses como Quetzalcóatl por su advocación de viento (Ehécatl) o Tláloc con su obvia asociación a conchas y caracoles marinos mantenían una estrecha relación con los dioses de la música. No obstante Macuil Xóchitl Xochipilli (Cinco flor, Señor de las flores) y Huehuecóyotl (Coyote Viejo) fueron considerados los dioses particulares de la música, regidores del canto, la danza y la poesía.

Poseían el vestuario y conocían coreografías, modulaciones del lenguaje y melodías propias de cada región. Tal como los mexicas traían cautivos a los dioses de las regiones conquistadas para celebrarlos en un recinto sagrado e integrarlos a su cosmogonía, así aprendían sus cantos y asimilaban tradiciones musicales de origen diverso. Heredan por línea directa el instrumental tolteca y teotihuacano y en su proceso de sedentarismo comienzan a desplegar rituales cada vez más complejos, asimilando otros legados de las culturas contemporáneas de Mesoamérica. El prestigio se refleja en ciudades y pueblos, donde en la casa de los señores mexica había una exigente demanda de buenos cantores y

9 Teonanácatl: Hongo divino, varios géneros de hongos psicotrópicos reciben este nombre (Conocybe, Panaeolus, Psathyrella, Psilocybe y Stropharia). Péyotl: Cactus alucinógeno (Lophophora Williamsii), ambos poderosos psicodislépticos. 


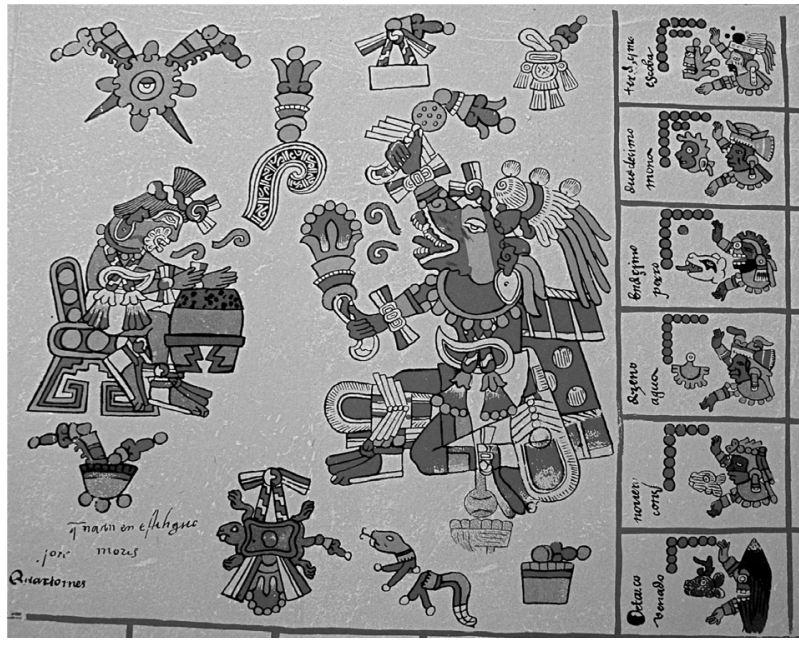

Ilustración 3, Dioses de la Música; Xochipilli ("El Señor de las Flores"), tañendo un pequeño huéhuetl y entonando un canto con vírgulas floridas; y Huehuecóyotl ("Coyote viejo"), que danza y canta con sonajas. Ambos portan el Mécatl (cordón con concha rebanada). Al pie se ve un Áyotl o concha de tortuga, también distintivo musical ${ }^{10}$.

buscaban que fuesen de buen ingenio para saber componer los cantares en su modo de metro o coplas que ellos tenían. Y cuando éstos eran buenos contrabajos tenían los en mucho, porque los señores en sus casas hacían cantar muchos días en voz baja. Ordinariamente cantaban en las principales fiestas, que eran de veinte en veinte días, y en otras menos principales ${ }^{11}$.

El canto tenía su representación pictográfica por medio de volutas que salían de la boca de sacerdotes o deidades. Las diversas inclinaciones, adornos o colores, significando variedades del canto, sugieren asimismo géneros y estilos que van desde el florido canto melismático de Xochipilli hasta las vírgulas direccionales de los cantos rogatorios que caen a la tierra para fertilizarla, himnos al dios de la vegetación y aun los curiosos cantares de tres conejos borrachos en la fiesta del pulque.

Fray Bernardino, en el décimo libro de su enciclopédica Historia General, "en que se trata de los vicios y virtudes, ansí espirituales como corporales, de toda manera de personas", nos da una completa semblanza de lo que significaba ser cantor en el mundo mexica.

El cantor alza la voz y canta claro. Levanta y baxa la voz, e compone cualquier canto de su ingenio. El buen cantor es de buena, clara y sana voz, de claro ingenio y de buena memoria, y canta en tenor, y cantando baxa y sube y ablanda o tiempla la voz, entona a los otros, ocúpase en componer y en enseñar la música, y antes que cante en público primero se ensaya. El mal cantor tiene voz hueca o áspera o ronca; es indocto y bronco; mas por otra parte es presumptuoso y jactancioso; es desvergonzado y invidioso, molesto y enojoso a los demás, por cantar mal, y muy olvidadizo, y avariento en no querer comunicar a los otros lo que sabe del canto, y soberbio y muy $\operatorname{loco}^{12}$.

\section{LA EDUCACIÓN MUSICAL}

La música formaba parte de la educación general impartida en las escuelas mexicas. Los calmecac y los tepochcalli; eran, "casa de jóvenes" donde se enseñaban además cantares y danzas. La nobleza ingresaba en los calmecac, "hileras de casas", centros de educación superior, de severa disciplina. Ahí aprendían cuidadosamente los cantares, los llamados cantos divinos valiéndose de las representaciones de los códices. Estos jóvenes educandos de ambas escuelas, eran los que realizaban las coreografías y la parte musical de danzas y cantares en las fechas sagradas. Junto con ellos había instrumentistas cuidadosos que conocían las concéntricas rondas de los bailes y el simbolismo de pasos, gestos y movimientos corporales, instruidos en la interpretación de los caracteres ideográficos capaces de preservar los versos y la métrica musical con que deberían ser cantados.

En la regla de la orden de Telpochtiliztli, consagrada en honra de Tezcatlipoca, los mancebos y doncellas vestían a imagen de este dios, y no les permitían vivir en congregación sino en sus casas, ya que

“... tenían una casa en cada barrio donde se juntaban cada día... luego que se ponía el sol, comenzaban sus ceremonias... tañendo, cantando y bailando asidos de las manos... hasta la media noche" $"$.

Ingresaban a esta orden desde pequeños y salían hasta el momento de contraer matrimonio. Otro centro de educación religiosa era el llamado Tlamacazcáyotl, en honra de Quetzalcóatl, servido por mancebos y doncellas quienes vivían en congregación como los sacerdotes y colegiales. Entre los oficios obligados era el baño a media noche y "velaban hasta las dos de la mañana, orando y cantando a su dios cantos y alabanzas; derramaban sangre de su cuerpo, al punto de la media noche" $"$. 


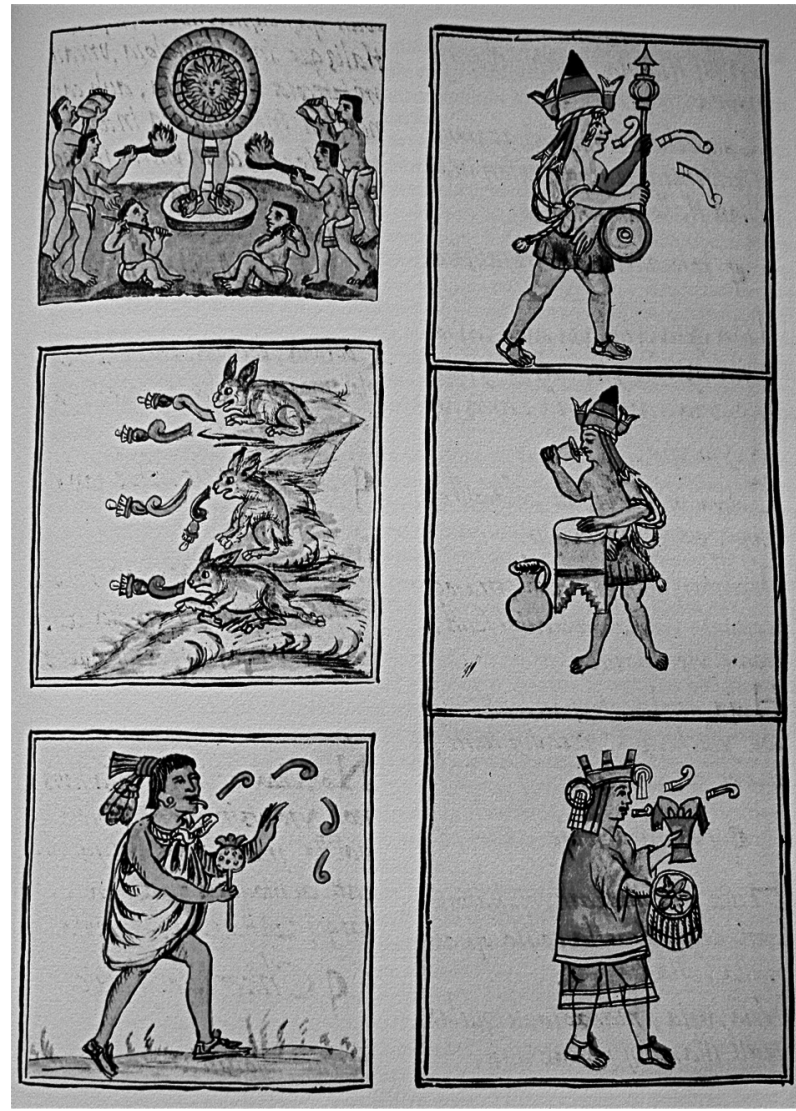

Ilustración 4, SAHAGÚN (1982): T. I, 80. Vírgulas de sonido: Cantos de embriaguez (conejos) e himnos de fertilidad, a la tierra y a la vegetación ${ }^{15}$.

Las escuelas donde se enseñaba y se aprendía específicamente la música y la danza eran los Cuicacalli. En las ciudades de la Triple Alianza - Tacuba-México-Texcoco-, "había casas de danza muy bien edificadas y galanas con muchos aposentos grandes y espaciosos, alrededor de un hermoso patio grande para el ordinario baile"16. Las casas de canto y danza de la ciudad se encontraban próximas al gran cerco almenado, el Coatepantli, que guardaba el recinto ceremonial de México-Tenochtitlán.

Estas casas de música dependían directamente del Mixcoatzalotla, encargado de instruir a los novicios en la conservación del fuego, la limpieza del templo y en tañer los instrumentos que señalaban las horas. En el Códice Florentino ${ }^{17}$ se encuentra el testi-

15 El informe académico que presentó al Colegio de Historia Alejandro Vega Pérez [VEGA (2013)], constituye una útil base de datos digital con imágenes y bibliografía comentada. Por otra parte, ya es posible consultar la mayoría de los códices digitalizados en línea.

16 DURÁN (1967): 128.

17 SAHAGÚN (1982): II, 392. monio de este proceso pedagógico. En la lámina de la derecha se encuentran instrumentistas y danzantes que tañen durante la noche, abajo vemos las guardias nocturnas, disciplina obligada del educando, para iniciar en el ritual y el misterio de las prácticas religiosas, aparecen más abajo los deberes en los templos; cargadores de leña.

De las torres de templos anunciaban las horas, noticias, llamadas y celebraciones designando a los sonoros aerófonos y percutores para extender las señales por los poblados del Anáhuac. El instrumental empleado regularmente consistía en

flautas, a manera de cornetas, y de unos caracoles que sonaban como bocinas, con éstas llamaban a las horas que se cantaban en el templo de día y de noche... hacían con esta solemnidad de instrumentos y atabales, cada mañana fiesta al sol, cuando salía, con armonía y estruendo singular y saludábanle de palabra... tañían de noche estos instrumentos otra vez... había veladores que velaban las vigilias de la noche, unos en los templos y otros en las encrucijadas de calles y caminos, su oficio era despertar a los sacerdotes y ministros para que acudieran a los sacrificios y horas nocturnas y, a los de la República para lo mismo, conforme estaban obligados ${ }^{18}$.

El aprendizaje de los nuevos músicos comenzaba con el rigor de estas responsabilidades; quienes no acudían prestos o eran negligentes recibían penas rigurosas.

Los areitos nocturnos representaban una forma de penitencia; cada noche se levantaban a danzar y bailar penetrando poco a poco en las enseñanzas rituales. Mantenían un estado de vigilia para no ser sorprendidos por los enemigos,

en todas las ciudades había junto a los templos unas casas grandes donde residían maestros que enseñaban a cantar y a bailar. A las cuales casas llamaban cuicacalli, que quiere decir casa de canto, donde no había otro ejercicio sino enseñar a cantar y a bailar y a tañer a mozas y mozos y era tan cierto el acudir ellos y ellas a estas escuelas y guardábanlo tan estrechamente que tenían el hacer falla como cosa de crimen lessae maiestatis ${ }^{19}$.

Las casas dedicadas a estas enseñanzas ya eran motivo en sí mismas de esparcimiento y roce social, siendo lugar de reunión obligado. Preparaban con ensayos los nuevos cantares y danzas de las fiestas mayores. Los atavíos de manta y plumas así como las máscaras, pieles, instrumentos, flores y comidas eran adquiridos en los mercados, para que nada faltara en la fiesta

y así, con los cantos nuevos, sacaban diferentes trajes ... rigiéndose por los cantos que componían y por lo que en ellos trataban, conformándolos con la solemnidad y fiesta, vistiéndose unas veces como águilas, otras como tigres y leones, otras, como soldados, otras como huastecos, otras como cazadores, otras veces como salvajes y como monos y perros y otros mil disfraces. ${ }^{20}$

18 TORQUEMADA (1975): cap. II, 227.

19 DURÁN (1967): cap. XXI, 189.

20 DURÁN (1967): 193. 


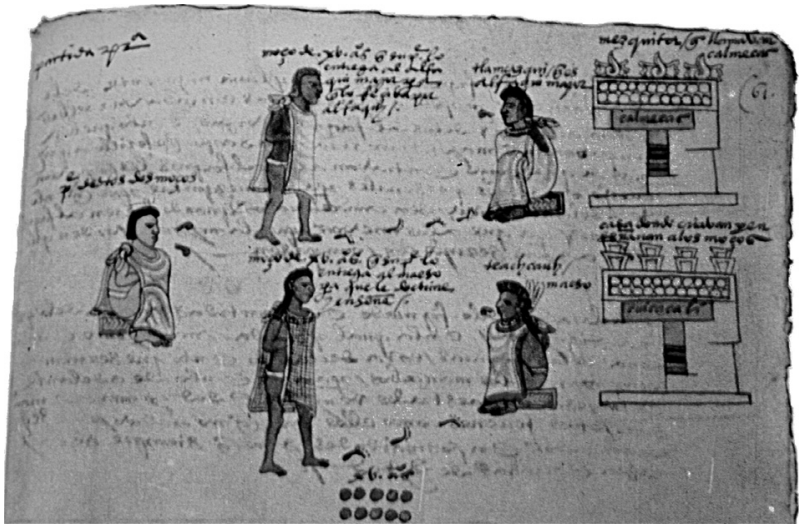

(Ilustración 5, Instrucción a mancebos en el Calmecac y el Cuicacalli, Códice Mendocino, Lámina LXII) ${ }^{21}$.

Las fiestas eran una ocasión para ganar prestigio, así que los señores procuraban abundancia en la comida, y perfección en las danzas llamadas macehualiztli:

Juntábanse muchos de dos en dos, o de tres en tres, en un gran corro, según la cantidad de los que eran, llevando flores en las manos, y ataviados con plumajes. Hacían todos a una un mesmo meneo con el cuerpo y con los pies y con las manos, cosa bien de ver y bien artificiosa. Todos los menos iban según el son que tañían los tañedores del atambor y teponaztli Con esto iban cantando con gran concierto todos, y con voces muy sonoras los loores de aquel dios quien festejaban... Enderezan los meneos, continencias y atavíos conforme a lo que cantan, porque usan diversísimos meneos y diversísimos tonos en el cantar; pero todo muy agraciado y aun muy místico ${ }^{22}$.

El Mecatlán era la "casa en la cual se enseñaba a tañer las trompetas a los ministros de los ídolos", y se encontraba dentro del recinto ceremonial de México-Tenochtitlan. El mécatl, cordel o soga, era un distintivo especial que caracterizaba al músico tañedor y se entregaba en esta casa tras una ceremonia privada. En el Mecatlán se enseñaban todos los instrumentos pero "en especial trompetas y flautas, de los cuales géneros usaban mucho en sus bailes y areitos" 23 .

La música cortesana se cultivaba en los palacios de los señores donde había salas dedicadas especialmente para la ejecución musical. El empleo y afición por la música tenía especial esplendor en las cortes de México y Texcoco; Moctezuma Xocoyotzin "servíase siempre con mucha música de flautas, zampoñas, caracoles, huesos, atabales y otros instrumentos...", en sus bailes y fiestas cantaban con voces concertadas al son de su teponaztli y al ritmo del huéhuetl, obligados acompañantes del canto. Cuando este Tlatoani daba por terminadas sus audiencias

21 KINGSBOROUGH (1964): vol. I, 128.

22 SAHAGÚN (1982): T.I, lib.1ํ, cap. XVI, 19-20.

23 TORQUEMADA (1975): lib. VIII, cap. XIV, 227. de Estado, "entraban señores y otras muchas cortesanas y gustaba de oír en sus cantares, las grandezas de sus antepasados"24. Netzahualcóyotl en su palacio de Texcoco, mandó construir "una sala de congregación donde se juntaban todos los poetas y hombres músicos (que lo eran muchos los de esta tierra), astrólogos e historiadores y de otras artes, donde conferían estas cosas con grande ciencia y que para más autorizar esta sala hizo presidente de ella a un hijo suyo, llamado Xochiquetzaltin"25.

\section{LA ORGANIZACIÓN DEL SERVICIO MUSICAL}

El servicio musical de los templos y adoratorios se organizaba, como ha quedado señalado, desde los establecimientos educativos ya que los padres tenían por costumbre llevar a sus hijos para ofrecerlos al servicio de los templos donde aprendían desde temprana edad a "tañer los caracoles o cornetas y los atabales y trompetas" 26 . Estas prestaciones de servicio ritual tenían carácter obligatorio y eran parte de una instrucción que los calpullis de cada barrio impartían a los jóvenes hasta llegar a la adolescencia,

"mancebos (y) doncellas... cuando se ponía el sol comenzaban sus ceremonias y ejercicios tañendo, cantando y bailando asidos de las manos moços y moças hasta la medianoche"27.

Estos danzantes, músicos e instrumentos se encuentran representados ejecutando la Danza Tlanahua de coreografía circular, con un guía que porta un emblema en forma de abanico.

Los tequihuaques, profesionales en un oficio o en la guerra, iban a estos lugares con el fin de relacionarse con la que sería su mujer, principalmente a través de ciertas danzas de cortejo con las que provocaban la atracción entre los jóvenes. Las danzas de fertilidad que ocupan la mayor parte de la actividad ritual mexica, son testimonio de la motivación sexual, regenerativa y fértil, que pretendía sostener y preservar la vida en todas sus formas. Los santuarios y templos principales, y en especial el de Huitzilopochtli contaban con un variado personal encargado de diversas funciones: el oficio consistía no sólo en cantar en los cúes, sino en componer los cantos que habían de ejecutarse, por lo que también lo llamaban Cuicapique (compositores de cantos).

"Había... cantores que componían cantares divinos, de las grandezas y alabanzas de los dioses, y éstos estaban en los templos; los cuales así los unos como los otros, tenían sus salarios, y a los cuales llamaban Cuicapique, que quiere decir "componedores de cantos"28.

24 TORQUEMADA (1975): lib. II, cap. LXXX-VIII, 314-315. 25 TORQUEMADA (1975): lib. II, cap. CLI, 204. 26 TORQUEMADA (1975): lib. II, 187. 27 TORQUEMADA (1975): lib. II, 221. 28 DURÁN (1967): lib. I, cap. XXI, 195. 


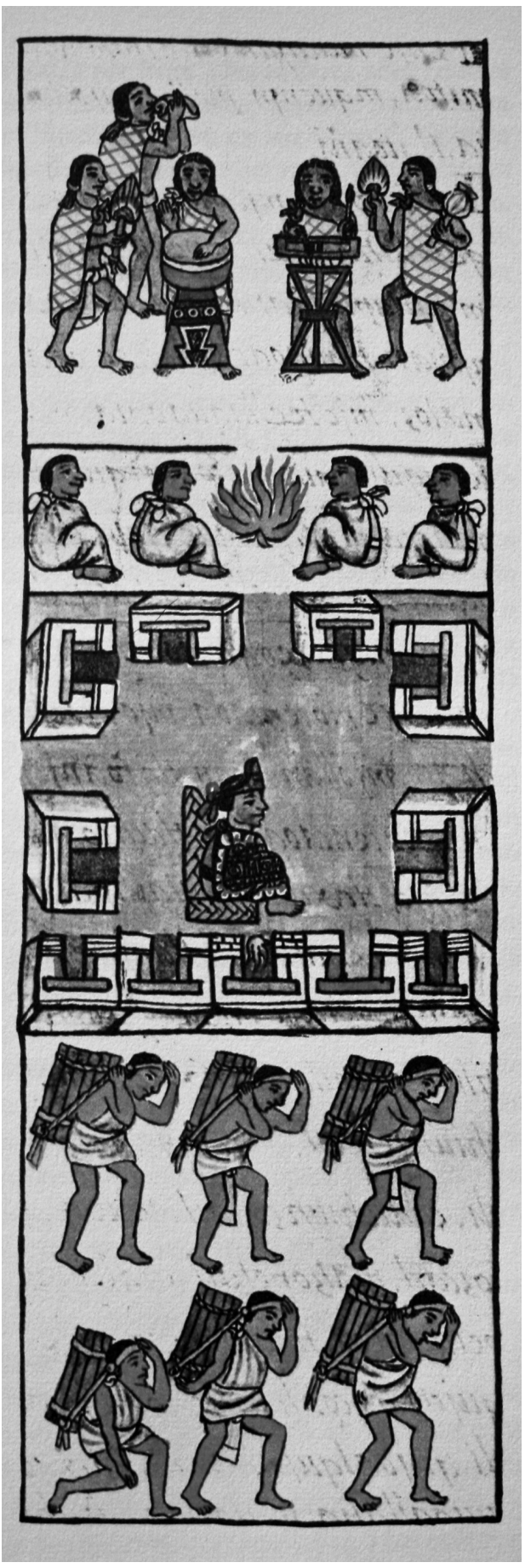

Ilustración 6, Velas nocturnas, músicos, custodios y leñeros ${ }^{29}$.

29 KINGSBOROUGH (1964): vol. I, 128.

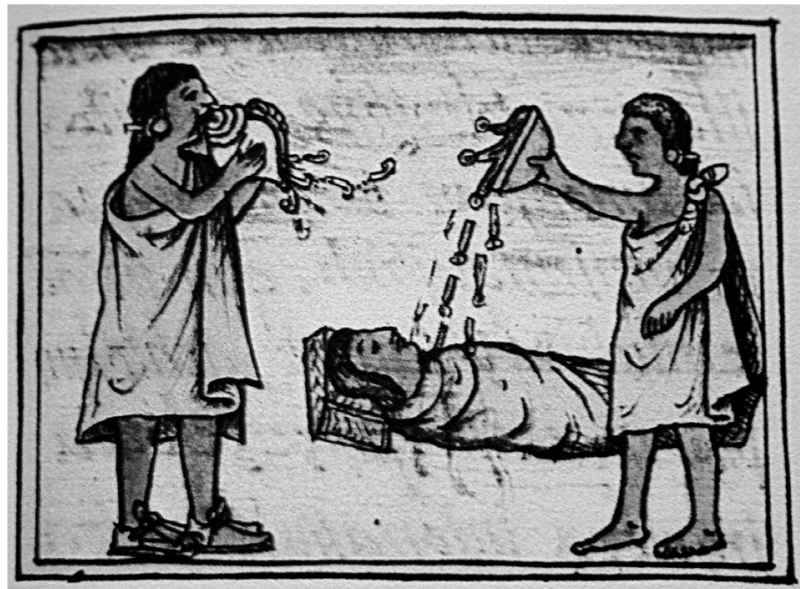

Ilustración 7, Despertar a media noche para cumplir los deberes rituales ${ }^{30}$.

El tlanamácac o representante del dios del pulque, "tenía cuidado de los vasos en que bebían los cantores... y de hincharlos de aquel vino... Teooctli o Macuiloctli" ${ }^{\prime 1}$. En cierta ceremonia, él tenía cargo de colocar doscientas tres cañas con las que sorbían la bebida, de las cuales sólo una estaba perforada; aquel que acertaba a tomar ésta, bebía él solo y nadie más. La ceremonia se realizaba después del oficio de haber cantado.

El Tlapizcatzin, "señor de la casa de las flautas", correspondiente a los chantres catedralicios, era el encargado de enseñar y corregir los cantos, "residía en los templos... por estar a su cargo comenzar los cantares e himnos... éste, llevaba el compás en el teponaztli" ${ }^{32}$. También instruían y dirigían a las jóvenes novicias en el aprendizaje de los cantares. Se encargaban de proveer los instrumentos en el Mecatlán, supervisando quién daría el tono, quién dirigiría, quién tañería las percusiones y anunciaba el orden de lo que debía cantarse y las prácticas o ensayos. Cantaban con un sistema de sílabas repetidas que les servían para medir el ritmo de la música ${ }^{33}$. Poco se sabe respecto a la grafología musical indígena. Stevenson ${ }^{34}$ discute, glosa y compara las opiniones en torno a la función del teponaztli como acompañante de los Cantares en lengua mexicana, cuyas conspicuas indicaciones rítmicas y su transcripción a caracteres actuales han suscitado hipótesis de gran interés. Parece evidente que era una ayuda nemotécnica que tenía relación con el pulso rítmico del verso, que se subrayaba con la percusión de dos tonos que produce el teponaztli y con una directa correspondencia coreográfica. Fray Diego Durán nos anima a penetrar en los enigmas de los cantares a través de un entendimiento profundo.

30 SAHAGÚN (1982): I,132.

31 SAHAGÚN (1956): apéndice IV, 249.

32 TORQUEMADA (1975): lib. II, 181-179.

33 GARIBAY (1970): XXXVIII.

34 STEVENSON (1971): 41-54. 
todos los cantares de éstos, son compuestos por unas metáforas tan oscuras que apenas hay quien las entienda si muy de propósito no se estudian y platican para entender el sentido de ellas. Yo me he puesto de propósito a escuchar con mucha atención lo que cantan y entre las palabras y términos de la metáfora y paréceme disparate y, después, platicado y conferido, son admirables sentencias, así en lo divino que agora componen, como en los cantares humanos ${ }^{35}$.

Tzapotlateohuatzin era el nombre que tenía el sustituto o sochantre, cuando por "muy grande, y legítima causa" 36 faltaba el Tlapizcatzin, a fin de que los jóvenes del coro no perdiesen ni un solo día de práctica en sus cantares.

El oficio del Tlamacazeateutl era el de maestrescuela, "casi maestro u oficial de mozos... cuyo oficio, entre otros... es enmendar a los que yerran en el coro" ${ }^{37}$.

El Epcoaquacuiltzin Tec Pic Toton era un poeta compositor, al que se le encomendaba hacer "los cantares que de nuevo eran menester, así para los cúes como para las casas particulares"38. Tenía un cargo de importancia vital por ser un experto en el calendario ritual ya que conocía perfectamente el orden de las ceremonias y supervisaba lo que se debía de hacer en las fiestas para que nada se omitiese. Los Tlamacazque o Tlamacazton ${ }^{39}$ eran jóvenes ya llegados a la edad de casamiento y de marchar a la guerra. Servían por un año en el templo y ahí sacralizaban su relación con el matrimonio. Eran los encargados de tañer las horas "En lugar de campanas tomaban... unos caracoles grandes y otros unas flautillas y tañían gran rato un sonido triste" 40 . Torquemada los llama teotlamacazque "moços de la casa de Dios" ${ }^{41}$. Estos mozos del servicio del templo les enseñaban

"cómo habían de barrer y con qué reverencia habían de tratar el fuego de los braseros ordinarios y las velas de la noche. y tañer los caracoles o cornetas y los atabales y trompetas y a mecer la tinta, con que se teñían... los sacerdotes" ${ }^{42}$.

Las Cihuatlamacazque o Cihuaquaquitli eran a modo de sacerdotisas, que en fechas señaladas bailaban, especialmente en aquellas que correspondían al templo a cuyo servicio estaban. El padre Acosta escribe:

estaban tan acordes, que daban en su sonido una bastante buena armonía, y acompañaban estos instrumentos, varias

35 DURÁN (1967): lib. I, cap. XXI, 195-196.

36 TORQUEMADA (1975): lib. IX, cap. VI, 264.

37 TORQUEMADA (1975): lib. IX, cap. VI, 264.

38 SAHAGÚN (1956): lib. II, apéndice IV, 251.

39 CASO (1933): VIII.

40 DURÁN (1967): 54

41 TORQUEMADA (1975): II, 178.

42 TORQUEMADA (1975): lib. IXC, cap. XIII, 275. Para una lista detallada de funciones sacerdotales en los templos véase SAHAGÚN (1956): lib. II, apéndice IV, 248-252. Sólo se tratan en este trabajo las que tenían relación con cantares y danzas. y diversas clases de aires y canciones. Cantaban y bailaban todos al son y cadencia de estos instrumentos con tan bello orden y tan bello compás o acuerdo, tanto en las voces como en el movimiento de los pies, que era cosa agradable de $\operatorname{ver}^{43}$.

\section{LAS DANZAS}

La participación colectiva en la danza estaba jerarquizada y estas categorías se reflejaban directamente en las coreografías. Tlatoanis y sumos sacerdotes en sitios principales, guerreros y cantores en círculos concéntricos, simples novicios en las cuadrillas exteriores. Esto supone una afirmación objetiva del poder y por otro lado un profundo conocimiento musical del señor, ya que él era el que decidía lo que se iba a cantar, el tono, y la colocación de los danzantes.

También mandaba hacer aquellas puntas de Ulli con que tañen el teponaztli, y que el teponaztli y atambor (huéhuetl) fueran muy buenos; también mandaba los meneos que había de haber en la danza, y los atavíos y divisas con que se habían de componer los que danzaban; también señalaba los que debían de tañer el atambor y teponaztli, y los que habían de guiar la danza o baile, y señalaba el día del baile, para alguna fiesta señalada de los dioses... y andando en el baile, si alguno de los cantores hacía falta en el canto, o si los que tañían el teponaztli y atambor faltaban en el tañer o si los que guían erraban en los meneos y continencias del baile, luego el señor los mandaba prender y otro día los mandaba matar ${ }^{44}$.

El tema más recurrente en las danzas mexicas a lo largo de los meses de su año ritual de 360 días, es el de la serpiente. En varias ocasiones durante el Cempoalapohualli ${ }^{45}$ o cuenta de los 18 meses de 20 días, vemos pintadas en códices o descritas por cronistas estas danzas donde las coreografías y símbolos giran en torno a este animal sagrado. Pasemos a describir las más notables.

La danza Mococoloa o de la culebra. Era una ocasión precisa para mostrarse los unos a los otros, coquetear y entablar relaciones más estrechas y duraderas ${ }^{46}$. Resultaban provocativos los atavíos de esta danza y la coreografía próxima y sugestiva "eran bailes y cantos de placer, que ellos llamaban 'bailes de mancebas', en las cuales cantaban algunos cantares de amores y requiebros" $"$. Se repetía al menos tres veces al año en ocasión de las fiestas de Huitzilopochtli y tenía una función específica según el mes en el que se ejecutaba.

43 MARTÍ (1955): 35.

44 SAHAGÚN (1982): II, lib. VIII, cap. 17, párrafo tercero "De la manera de los areitos", 401.

45 Ver Calendario Ceremonial Mexica, en GUZMÁN (1984): capítulo VI.

46 DURÁN (1967): cap. XXI, 192.

47 DURÁN (1967): cap. XXI, p. 193. 
La danza Tlanahua durante el mes Tóxcatl. los sacerdotes como organizadores de los ritos siempre se han reservado convenientes prerrogativas, tal era la danza que precedía a la de la culebra y venía a ser su preparación y primicia.

Los ministros del templo convocaban a las doncellas para bailar Tlanahuatoxca chocholoa, que se caracteriza por sus saltos y por los círculos que hacían los sacerdotes en torno a las jóvenes. Apoyaban en el suelo un cetro rematado con una bola de pluma negra, alusión al mito del origen del dios Huitzilopochtli que recreaba el proceso de fecundación milagrosa.

"Coatlicue hacía penitencia barriendo... (en el templo de Coatepec) y un día descendióle una pelotilla de pluma, como ovillo de hilado y tomóla y púsola en el seno junto a la barriga, debaxo de las naguas y después de haber barrido (la) quiso tomar, y no la halló, de que dicen se empreñó"

Este cetro usado como la coa de la siembra sugiere coreografías eróticas a fin de preparar a las doncellas para recibir marido. Esta danza se develaba en patios secretos, alejados de músicos e invitados. Mientras tanto...

Toda la gente del palacio y la gente de guerra viejos y mozos, danzaban en otras partes del patio, trabados de las manos y culebreando a manera de las danzas que los populares hombres y mujeres hacen en Castilla la Vieja...

Entre éstas danzaban las mujeres doncellas... a esta manera de danzar llaman Tlanahua, que quiere decir abrazado, Quinahua in Huitzilopochtli, abraza a Huitzilopochtli. Todo esto se hacía con gran recato y honestidad; y si alguno hablaba o miraba deshonestamente, luego le castigaban porque había personas puestas que velaban sobre esto, estos bailes y danzas duraban hasta la noche ${ }^{49}$.

La danza de la culebra, se efectuaba durante el mes Tlaxochimaco (noveno mes). Se efectuaba tres meses después de la fiesta del tiempo de secas cuando venía la de recolección de flores para celebrar ofrendas y establecer enlaces nupciales. En este baile los guerreros repartidos en seis categorías, tenían privilegio de estrechar por la cintura a las mujeres que en este caso no eran sirvientas del templo sino "mozas públicas" y no contaban con miradas de reprobación ya que consta que los mayores se dedicaban por su parte a beber vino y emborracharse.

También en esta danza entraban mujeres, mozas públicas e iban asidos de las manos, una mujer entre dos hombres, un hombre entre dos mujeres, a manera de las danzas que hacen en Castilla la Vieja la gente popular; y danzaban culebreando y cantando, y los que hacían el son para la danza y los que regían el canto estaban juntos, arrimados a un altar redondo... en esta danza no hacían vueltas ninguna, más de ir con pasos llanos al compás del son y del canto muy despacio, nadie osaba hacer ningún bullicio ni atravesar por el espacio donde danzaban; todos los danzantes iban con gran tiento que no hiciesen alguna disonancia.

Los que iban a la delantera que era la gente más ejercitada en la guerra, llevaban echado el brazo por la cintura de la mujer como abrazándola; los otros que no eran tales, no tenían licencia de hacer esto. A la puesta del sol cesaba este areito y se iban todos para sus casas y lo mismo hacían en cada casa, cada uno delante de sus dioses había gran ruido en todo el pueblo por razón de los cantares y del tañer de cada casa... Los viejos y viejas bebían vino a emborracharse ${ }^{50}$.

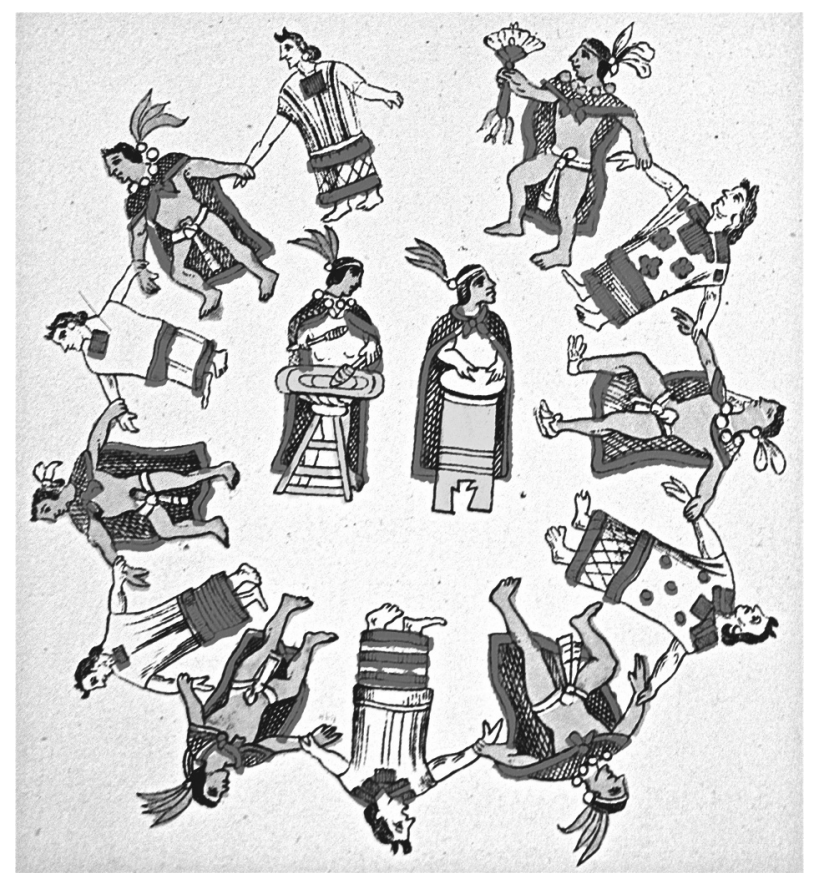

Ilustración 8, Danza Tlanahua; jóvenes de ambos sexos danzan regidos por el huéhuetl y el teponaztle ${ }^{51}$.

Este "danzón a lo divino", se extendía por toda la ciudad y concluía al tiempo de seleccionar el árbol que deberían adornar con Axacachtlis y banderas para la fiesta de Xócotl Huetzi en honor del Dios del Fuego. En el Códice Borbónico se encuentra representada esta ceremonia, de Xócotl; donde alrededor de un gran palo adornado, unos danzantes asidos de la mano bailan en torno de este árbol simbólico adornado con banderas de papel amate y sonajas, los acompaña un tañedor de huéhuetl. La danza la integran sujetos de diversas categorías, el guiador de la danza era el de condición más elevada mientras que los humildes estaban al final de la fila, y ésta no es cerrada, así los distintos estratos sociales no se juntaban ni tocaban.

50 SAHAGÚN (1982): I, lib. II, cap. XXVIII, 93-94. 51 DURÁN (1967): Atlas, lámina XXX.
48 SAHAGÚN (1982): I, lib. III, cap. I, párrafo $1^{\circ}, 144$. 49 SAHAGÚN (1982): I, lib. II. cap XXIV, 78. 


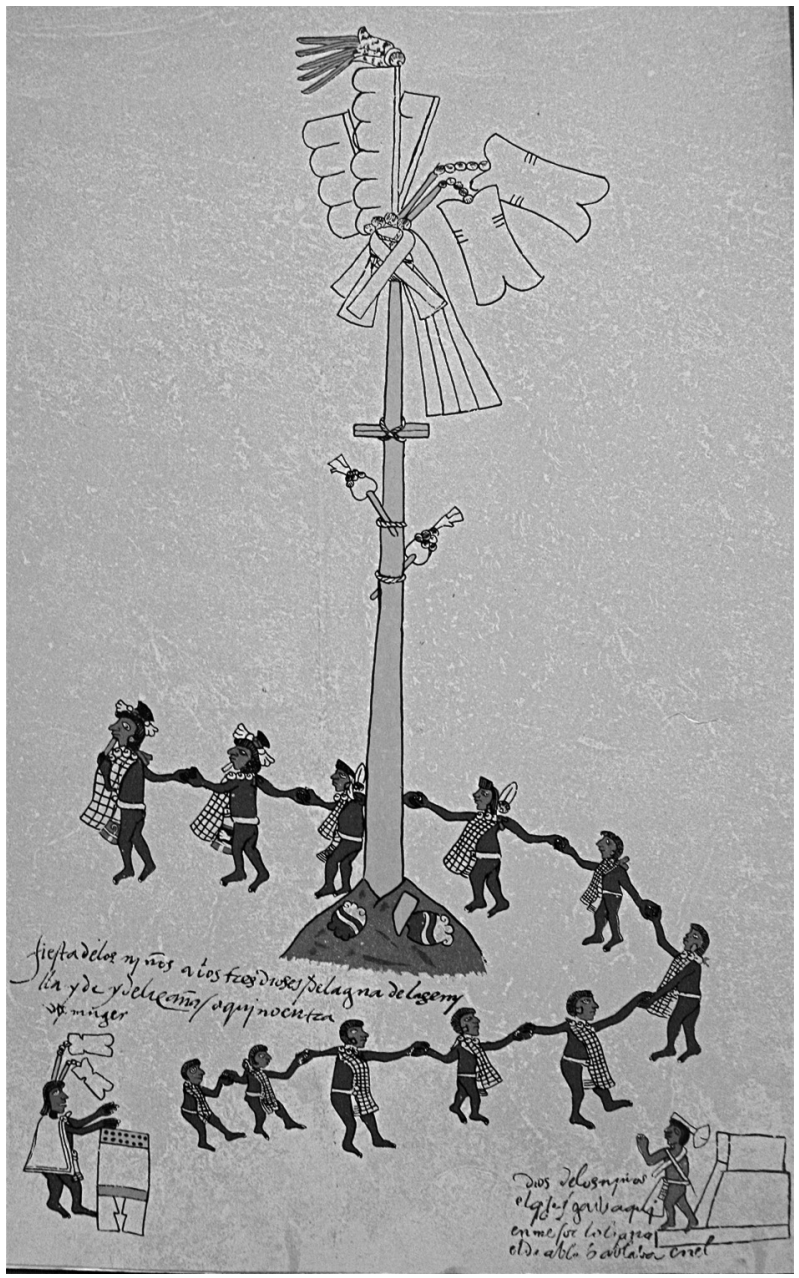

Ilustración 9, Danza masculina de Xócotl Huetzi, la fila india no se cierra. Acompaña un tañedor de huéhuetl ${ }^{52}$.

Las fiestas del noveno mes (Tlaxochimaco), celebradas según Torquemada a partir del 15 de julio eran de gran regocijo; se repartían 17 clases específicas de flores y había abundancia en el comer y beber. Era famosa y célebre por su vistosidad la danza Coanecuilolo en el mes Panquetzaliztli. Una compleja forma de danza de serpiente se realizaba esta vez en mayor escala con motivo de la fiesta mayor del Dios Huitzilopochtli...

Comenzábase esta fiesta el día segundo de este mes haciendo grandes bailes, y cantando los cantares, y alabanzas de su dios Huitzilopochtli, en el patio de su detestable templo. En el baile andaban hombres y mujeres todos juntos; comenzábase sobre la tarde, o a la caída del sol, y acabábase

52 Códice Borbónico: lámina XXVIII. a las nueve o a las diez de la noche; esto era por veinte días continuos $^{53}$.

Durante este mes, que significa enarbolamiento de pendones o banderas se preparaba la guerra ritual con la celebración de una danza general en la que participaban por igual señores y esclavos preparando el momento del sacrificio tras de cuatro días de ayuno. Se daba comienzo a la caída de la noche y también consistía en danzas concéntricas abrazados por el cuello o trabados de manos y no sólo se realizaba en el templo sino en todas las casas de los principales ya que era "el mes más festejado y de los mayores sacrificios en todo el año" ${ }^{54}$. Estas danzas de la culebra cerraban todo el ciclo de concepción, nacimiento y combate de Huitzilopochtli; los círculos eran delimitados con guirnaldas y los movimientos eran vivos, "con gran prisa saltando y corriendo y danzando, galopando y acezando y las viejas de los barrios íbanles haciendo el son y cantando" 55 . Los diferentes pasos amplificados por los atavíos de sartales de conchas y cascabeles, sonaban como el crótalo de una enorme serpiente, atributo del poder fecundador y destructor. El solemne ondular serpentino de coreografias disfrazadas por siglos de persecución, aún retiene en algunas comunidades de México, Guatemala y Nuevo México su atavismo ancestral.

La danza en general y particularmente las dedicadas al dios Huitzilopochtli son resultado de una añosa tradición mesoamericana y a la propia de los aztecas. Este dios totémico, central en la cosmogonía mexica, guió con su canto a su pueblo, lo sacó de Aztlán y los llevó peregrinando hasta encontrar el asentamiento definitivo en Tenochtitlan.

Huitzilopochtli mismo ha bailado y exige un sacrificio ritual. El tlatoani Chimalpopoca de Tenochtitlan, afrentado en su honor y convertido en cautivo en su propio estado, por Maxtla, señor de Atzcapotzalco, decidió ofrecerse en sacrificio a Huitzilopochtli; consultó su decisión con Tlacateotl, señor de Taltelolco y resolvieron morir

... como ciertos antepasados murieron en Atlauhpulco, que fue haciendo un baile sacrificándose en él a su dios Huitzilopochtli todos los señores que en él bailaron... el rey puso en ejecución el propósito que tenía para lo cual(señalando el día) se vistió de los vestidos de su dios Huitzilopochtli y con él muchos señores y señoras principales, los cuales habían de morir con él juntamente; comenzaron a bailar y a la hora determinada, cuando comenzaban en semejantes bailes de sacrificios... comenzó el ministro a matar por su orden a los que bailaban ${ }^{56}$.

Pero los tepanecos llegaron justo a tiempo de prenderlo y llevárselo prisionero a presentar a Maxtla, en Atzcapotzalco, donde fue reducido a prisión, ahorcándose él mismo. Además

53 TORQUEMADA (1975): II, 281-282. 54 TORQUEMADA (1975): II, 281-282. 55 SAHAGÚN (1956): I, 208.

56 TORQUEMADA (1975): cap. XXVIII, lib. II, 174. 
de las danzas de serpiente hay una que fue muy popular y que subsiste en la actualidad, de la cual Motolinía nos deja una excelente descripción: La danza llamada Mitote.

Llegados los bailadores al sitio, poníanse en orden a tañer los atabales, y los cantores, las mujeres, como sochantres comienzan... allí los cantos... Queriendo comenzar a bailar, tres o cuatro indios levantan unos silbos muy vivos, luego tocan los atabales en tono bajo, y poco a poco van sonando más. Y oyendo la gente bailadora que los atabales comienzan por el tono de ellos, entienden en cantar el baile y luego lo comienzan. Los primeros cantos van en tono bajo, como bemolados, y despacio, y el primero es conforme a la fiesta, y siempre le comienzan aquellos dos maestros, y luego todo el coro lo prosigue juntamente con el baile... De manera que los atabales y el canto y los bailadores, todos llevan su compás concertado, y todos son conformes que no discrepan uno de otro una jota: de lo cual los buenos danzadores de España que los ven se espantan y tienen en mucho las danzas y bailes de éstos... Cada verso o copla repiten tres o cuatro veces y van procediendo y diciendo su cantar bien entonados, que ni en el canto, ni en los atabales, ni en el baile, sale uno de otro... Acabado de cantar (dado caso que los primeros parecen más largos por ir más despacio, aunque todos no duran más de una hora), apenas el atabal muda el tono, cuando todos dejan de cantar, y hechos ciertos compases de intervalo (en el canto más no en el baile), luego los maestros comienzan otro cantar un poco más alto y el compás más vivo, y así van subiendo los cantos y mudando de tonos y sonidos, como quien de una baja muda y pasa a una alta, y de una danza en un contrapás ... Desde la hora de vísperas hasta la noche, los cantos y bailes se van más avivando, y alzando los tonos, y la sonada es más graciosa que parece que llevan un aire de himnos que tienen el canto alegre... y cierto todo era cosa de ver ${ }^{57}$.

A no dudarlo estas danzas serían "cosa de ver" y también de oír y entender, pero las secretas coreografías, cantares y perplejos ritmos han quedado en las sombras de la historia.

Subsisten no obstante, noticias de mitotes entre tepehuanos, coras y huicholes, danzas de quetzales, huehues y voladores entre totonacos, huaxtecos y nahuas, además de otras danzas practicadas en los pliegues de las serranías o en el espeso trópico donde podemos reconocer elementos de franca raíz prehispánica. Sin embargo el grueso de las danzas indígenas se asimilaron durante el virreinato a las necesidades del rito cristiano. Suntuosos mitotes fueron desplegados en grandes ocasiones como el recibimiento de virreyes, arzobispos o nuncios apostólicos. Instrumentos, géneros musicales y coreografías se reinterpretaron a la luz de los nuevos símbolos. Es con base a este proceso de aculturación que podemos entender la actual danza indígena, producto de la rica herencia mesoamericana, del espíritu misional que privó en los tres siglos de cristiani-

57 MOTOLINÍA (1970): lib. IV, cap. XXVII zación y de la incorporación de elementos africanos, moriscos, orientales y de otras etnias que se establecieron por los confines de América.

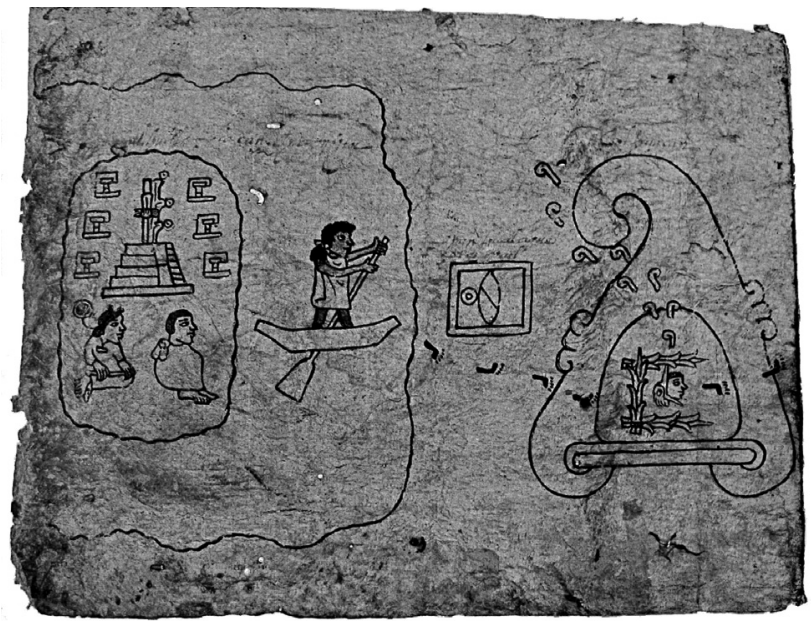

Ilustración 10, Huitzilopochtli guía con sus vírgulas de canto a los mexicas en su peregrinación para fundar Tenochtitlan ${ }^{58}$.

Este es ahora el paso del indio que encarna los combates del señor Santiago contra los moros o que canta las alabanzas con ecos de conchas conquistadoras, es aquel que imita al capataz negro del trapiche, al francés napoleónico o al judío del que sólo escuchó mención en pasajes bíblicos. Sus máscaras, sus trajes, sus músicas y cantares son como antaño reinterpretación de un universo dinámico, donde la creatividad encuentra expresión dando cuerpo a la rica tradición de la danza indígena en México.

\section{BIBLIOGRAFÍA}

Acosta, José de, Historia natural y moral de las Indias. Sevilla, Juan de León, 1590 [Madrid, Ed. Atlas, "Biblioteca de Autores Españoles, LXXIII", 1954.

Aguilera García Aguilera, María del Carmen, Coyolxauhqui: Ensayo Iconográfico. México, Biblioteca nacional de Antropología e Historia, Cuadernos de la Biblioteca, INAH, 1978.

Alcalá, fray Jerónimo de, Relación de las ceremonias y ritos, etc., de los Indios de la Provincia de Michoacán, 1541 [Madrid, Aguilar, 1956].

Alva Ixtlixóchitl, Fernando de, Historia de la nación chichimeca. [1610-1640]. Ms. C. 44-45-46

Alva Ixtlixóchitl, Fernando de, Obras Históricas. México, Ed. Nacional, 1952.

Alvarado Tezozomoc, Hernando, Crónica Mexicana. [1598c]. México, Ed. Leyenda, 1944.

58 Códice Boturini o Tira de la Peregrinación (1980): lámina $1^{\mathrm{a}}$. 
Ancona H., Ignacio; y Martín del Campo, Rafael, Malacología Precortesiana. México, UNAM, 1953.

Ayala Falcón, Maricela, "La escritura, el calendario y la numeración", (Manzanilla, Linda; y López Luján, Leonardo, eds.) Historia antigua de México. Vol. IV. México, INAH, UNAM, Porrúa, 2001.

Aveni, Anthony F., Observadores del cielo en el México antiguo. México, FCE, 2005.

Baqueiro Foster, Jerónimo, "El secreto armónico y modal de un antiguo aire maya", Los mayas antiguos. México, El Colegio de México, 1941.

Barlow, Robert H., "El Códice Azcatitlán”, Journal de la Societé des Americanistes, XXXVIII y suplemento (1949), 101-135.

Beyer, Hermann. "Una representación actual del uso del Omichicahuaztli", Mémoires y Revista de la Sociedad científica Antonio Alzate, t. 34 [sesión del 3 de noviembre de 1914] (1916), 129-136.

Blom, Franz, The Conquest of Yucatán, Boston, H. Mifflin, 1936.

Boilés, Charles Lafayette, The Pipe and Tabor in Mesoamerica. Nueva Orleáns, Universidad de Tulane, Year Book II, del Instituto Latinoamericano de Investigaciones Musicales, 1966.

Both, Arnd Adje, Los aerófonos mexicas en las ofrendas del recinto sagrado de Tenochtitlan. Tesis de doctorado en ciencias culturales, Alemania, Universidad Libre de Berlín, 2005.

Both, Arnd Adje, "La Música Prehispánica. Sonidos rituales a lo largo de la historia", Revista de Arqueología Mexicana, 94 (2016), 28-37.

Campos, Rubén M., El folklore y la música mexicana. México, SEP, Talleres gráficos de la nación, 1928.

Campos, Rubén M., El folklore musical de las ciudades. México, Secretaría de Educación Pública, Talleres linotipográficos El Modelo, 1930.

Casas, fray Bartolomé de las, Los indios de México y Nueva España. (Edmundo O’Gorman ed.). México, Porrúa, 1974.

Caso, Alfonso, "Ensayo de interpretación del disco estelar que aparece en los tres fragmentos del huéhuetl del Ozomatli”, Anales del Museo Nacional de Arqueología, Historia y Etnografía, 4a época/vIII (1933).

Caso, Alfonso, El pueblo del sol. México, FCE, 1953 [2012].

Caso, Alfonso, Interpretation of the Codex Bodley 2858. México, Sociedad Mexicana de Antropología, 1960.

Caso, Alfonso, Los Calendarios Prehispánicos. México, IIH, UNAM, 1967.

Castañeda de la Paz, María, Conflictos y alianzas en tiempos de cambio: Atzcapotzalco, Tlacopan, Tenochtitlan y Tlatelolco (siglos XII-XVI). México, UNAM, IIA, 2013.

Castañeda, Daniel y Mendoza, Vicente T., "Los teponaztlis, los percutores precortesianos y los huéhuetls", Anales del Museo Nacional de Arqueología, Historia y Etnografía, 4a época/VIII (1933), 5-80.
Castañeda, Daniel y Mendoza, Vicente T., Instrumental Precortesiano. 2 vols. México, Imprenta del Museo Nacional de Arqueología, 1933.

Castellanos, Pablo, Horizontes de la Música Precortesiana. México, FCE, 1970.

Ciudad Real, Antonio de, Relación breve y verdadera de algunas cosas de las muchas que sucedieron al padre fray Alonso Ponce en las provincias de Nueva España. Madrid, Impr. de la Viuda de Calero, col. "Documentos Inéditos para la Historia de España, LVII-LVIII", 18721873.

Clavijero, Francisco, Historia antigua de México. México, Porrúa, 1945.

Covarrubias, Sebastián de, Tesoro de la lengua castellana o española. Madrid, Luis Sánchez, 1611. [Barcelona, Horta, 1943].

Contreras, Guillermo, Atlas cultural de México: Música. México, SEP, INAH, Planeta, 1988.

Chamorro, Arturo, Los instrumentos de percusión en México. México, El Colegio de Michoacán, CONACYT, 1984.

Chase, Gilbert, A Guide to the Music of Latinamerica. Washington, Librería del Congreso, Unión Panamericana, 1962.

Chávez, Carlos, La Música; México en la Cultura. México, Secretaría de Educación Pública, 1946.

Chimalpahin Cuauhtlehuanitzin, Domingo Francisco de San Antón Muñón, Anales. México, Rendón, 1966.

De la Fuente, Beatriz, La pintura mural prehispánica de México. 3 vols. México, IIE, UNAM, 1995.

Densmore, Frances, The American Indian and Their Music. Nueva York, Prensa de la Mujer, 1926.

Díaz del Castillo, Bernal, Historia Verdadera de la Conquista de la Nueva España. México, Porrúa, 1972.

Dos Santos, Natalino E. Tiempo, espacio y pasado en Mesoamérica. El calendario, la cosmografía y la cosmogonía en los códices y textos nahuas. México, UNAM, IIH, 2014.

Dozier, Edward P., "Spanish Catholic Influences on Rio Grande Pueblo Religion", American Anthropologist, 60/3 (jun. 1958), 441-448.

Durán, fray Diego, Historia de las Indias de Nueva España e islas de la tierra firme. (Garibay Kintana, Ángel María, ed.). 2 vols. México, Porrúa, 1967 [México, CONACULTA, 1995].

Eboué, Félix, Les Peuples de L'Oubanqui-chari: essai d'ethnographie, de linguistique et d'économie sociale. París, Comité de l'Afrique française, 1933.

Elliott, John Huxtable, Imperial Spain 1469-1716. Cambridge, Cambridge University Press, 1963 [Londres, Penguin Group, 1975].

Escalante Gonzalbo, Pablo, Los códices mesoamericanos antes y después de la conquista española. México, FCE, 2010.

Farnsworth, Paul R., The Social Psychology of Music. Nueva York, Dryden, 1958.

Flores Dorantes, Felipe y Flores García, Lorenza, Organología aplicada a instrumentos musicales prehispánicos. México, INAH-SEP, 1981. 
Franco Carrasco, José Luis, Sobre un grupo de instrumentos prehispánicos con sistema acústico no conocido. México, Ed. Libros de México, 1964.

Galindo, Miguel, Nociones de historia de la música mejicana, T. I. Colima, Tipografía El Dragón, 1933.

Gallop, Rodney, "The Music of Indian Mexico", The Musical Quarterly, XXV/2 (April, 1939), 210-225.

Garibay Kintana, Ángel María, Épica náhuatl. México, UNAM, col. "Biblioteca del Estudiante Universitario", 1945 [1993].

Garibay Kintana, Ángel María (trad.), Manuscrito Palatino. XXXX, XXXX, 1953.

Garibay Kintana, Ángel María, Historia de la literatura náhuatl. México, Porrúa, 1953-1954.

Garibay Kintana, Ángel María, Poesía Náhuatl I. Romances de los señores de la Nueva España. Manuscrito de Juan Bautista de Pomar Tezcoco, 1582. México, UNAM, 1964.

Garibay Kintana, Ángel María, Teogonía e historia de los mexicanos; tres opúsculos del siglo XVI. México, Porrúa, 1965.

Garibay Kintana, Ángel María, Poesía Náhuatl II. Cantares Mexicanos. Manuscrito de la Biblioteca Nacional de México. Primera parte. México, UNAM, col. "Fuentes indígenas de la cultura náhuatl", 1965.

Garibay Kintana, Ángel María, Poesía Náhuatl III. Cantares Mexicanos. Manuscrito de la Biblioteca Nacional de México. Segunda parte. México, UNAM, IIH, col. "Fuentes indígenas de la cultura náhuatl", 1968.

Garibay Kintana, Ángel María, Llave del náhuatl. México, Porrúa, 1970.

Geijerstam, Claes af, Popular Music in Mexico. Albuquerque, University of New Mexico Press, 1976.

Génin, Auguste, "The Musical Instruments of the Ancient Mexicans", Mexican Magazin, III/7 (July, 1927).

Gillmor, Frances, Flute of the Smoking Mirror. Albuquerque, University of New Mexico Press, 1949.

Gómez, Luis Antonio, El libro de música mexica a través de los Cantares Mexicanos. México, Colegio Nacional de Bibliotecarios, 2001.

Gómez, Luis Antonio, "La documentación de iconografía musical prehispánica”, Revista Digital Universitaria, 7/2 (Febrero, 2006). [México; ISSN: 1067-6079].

Gutiérrez de Medina, Cristóbal, Viaje del virrey Marqués de Villena. (Romero de Terreros, Manuel ed.). México, UNAM, Instituto de Historia, 1947.

Guzmán Bravo, José Antonio, La música en México durante el Virreinato. México (inédito). [Talea No. 1, México, 1975, publica un fragmento de esta investigación].

Guzmán Bravo, José Antonio: La música en el ritual del dios Huitzilopochtli. Tesis, Ámsterdam, Jaap Kunst Centrum, Voor Etnomusicologie, Universiteit Van Amsterdam, 1977.

Guzmán Bravo, José Antonio, La Música de México. I. Historia, 1. Período prehispánico. (Estrada, Julio, ed.). México, IIE, UNAM, 1984. [Actualizada y revisada para reedición en 2018].
Guzmán Bravo, José Antonio, La Música de México. I. Historia, 2. Período Colonial. (Estrada, Julio, ed.). México, IIE, UNAM, 1984. [Actualizada y revisada para reedición en 2018].

Guzmán Bravo, José Antonio, "Del universo musical prehispánico", Armonía, I/1, [México, Escuela Nacional de Música, UNAM] (1993), pp. XX-XX.

Hammond, Norman, "Classic Maya Music. Part I: Maya Drums" and "Classic Maya Music. Part II: Rattles, Shakers, Raspers, Wind and String Instruments", Archaeology, 25/2 \& 25/3 (April, 1972 \& June, 1972), 124-131 \& 222-228.

Harcourt, Raoul D', “L'ocarina á cinq sons dans l'Amérique Préhispanique", Journal de la Société des Américanistes, XIII (1930), 347-364.

Harcourt, Raoul D', 'Sifflets et Ocarinas du Nicaragua et du Méxique", Journal de la Société des Américanistes, XXXIII (1941), 165-172.

Harrison, Frank U., Time, Place and Music. Ámsterdam, Fritz Knuf, 1973.

Harrison, Frank U.; and Harrison, Joan, "Spanish Elements in the Music of Two Maya Groups in Chiapas", Selected Reports in Ethnomusicology, 1/2 [UCLA] (1968), 1-44.

Hellmer, José Raúl, "Los antiguos mexicanos y su música”, Boletín Bibliográfico de la Secretaría de Hacienda y Crédito Público, X/286, Época Segunda (Enero, 1964), 12-17.

Hernández, Francisco, Antigüedades de la Nueva España. (García Pimentel, Joaquín, ed.). México, Pedro Robredo, 1945.

Herrera y Ogazón, Alba, El arte musical en México. México, Dirección General de las Bellas Artes, 1917.

Herskowitz, Melville J., "On Some Modes of Ethnographic Comparison", Bijdragen tot de Taal-, Land- en Volkenkunde, 1956.

Hickmann, Hans, "Le Problème de la Notation Musical dans L'Egypte Ancienne", Bulletin de L'Institut d'Egypte, XXVI, Session 1953-1954 [El Cairo] (1955).

Hood, Mantle, Institut of Ethnomusicology. Los Ángeles, Universidad de California, 1961.

Hornbostel, Erich Moritz von, Opera Omnia. La Haya, Martinus Nyhoff, 1975.

Hornbostel, Erich Moritz von; und Sachs, Curt, "Systematik der Musikinstrumente. Ein Versuch", Zeitschift für Ethnologie, 46/4-5 (1914), 553-590.

Ibarra, Fernando, Análisis formal de la vírgula de sonido en la pintura mural teotihuacana. Tesis de licenciatura en Historia, México, Facultad de Filosofía y Letras, UNAM, 2006.

Ibarra, Fernando, "Iconografía musical prehispánica": http// www. Revista UNAM. mx/vol.7/ num2/ art10/ int10.htm

Izikowitz, Karl Gustav, Musical and other Sound Instruments of the South American Indians. Gotemburgo, Elanders boktr, "Goteborgs kungl. Vetenskaps- och vitterhets-samhalles handlingar", 1935 [Musical Instruments of Souht American Indians. Gotemburgo, S. R. Publishers, 1970].

Jansen, Maarten, "Los fundamentos para una «lectura lírica» de los códices", en Estudios de Cultura Náhuatl, 3 (1999), 590. 
Jiménez Borja, Arturo, Instrumentos musicales del Perú. Lima, Museo de la Cultura, 1951.

Johannson K., Patrick, "Miccacuicatl: cantos mortuorios nahuas prehispánicos. Textos y contextos”, Estudios de Cultura Náhuatl, 48 (2014), 7-87.

Johannson K., Patrick, La palabra, la imagen y el manuscrito. México, UNAM, IIH, 2004.

Jung, Carl G., El hombre y sus símbolos. Barcelona, Biblioteca Universitaria, Caralt, 1977.

Kingsborough, lord Edward King, Antigüedades de México. México, Secretaría de Hacienda y Crédito Público, 1964.

Krickberg, Walter, Las antiguas culturas mexicanas. México, Fondo de Cultura Económica, 1961.

Kunst, Jaap, Ethnomusicology. La Haya, Martinus Nijhoff, 1959.

Kunst, Jaap; and Martí, Samuel, Dances of Anahuac. Chicago, Aldine Pub. Co., 1964.

Kurath, Gertrude Prokosch, "Panorama of dance ethnology", Current Anthropology, 1/3 (1960), 233-254.

Landa, fray Diego de, Relación de las Cosas de Yucatán. México, Pedro Robredo, 1938 [México, Ed. Porrúa, 1959].

Landa, fray Diego de, Diego de Landa's Sixteenth-century Relacion de las Cosas de Yucatán. (Tozzer, Alfred M., ed.). Cambridge Mass., Harvard University, The Museum, "Papers of the Peabody Museum of American Archaeology and Ethnology, 18”, 1941.

León Portilla, Miguel, Los antiguos mexicanos a través de sus crónicas y cantares. Ms. Romances de los Señores de la Nueva España. México, Fondo de Cultura Económica, 1961 [1972].

León Portilla, Miguel, Trece poetas del mundo azteca. México, UNAM, IIH, 1967 [1984].

León Portilla, Miguel, La filosofía náhuatl. México, UNAM, 1974.

León Portilla, Miguel, Toltecáyotl. Aspectos de la cultura náhuatl. México, FCE, 1980 [2014].

León Portilla, Miguel, El destino de la palabra. México, FCE, 1996 [2013].

León Portilla, Miguel, Cantares Mexicanos. 3 vols. México, UNAM, 2011.

Lomax, Alan, "Song Structure and Social Structure", Ethnology, 1/4 (January, 1962), 425-451.

López Austin, Alfredo, Textos de medicina náhuatl. México, UNAM, 1971 [2000].

López Austin, Alfredo, Hombre Dios. México, UNAM, 1973.

López Austin, Alfredo, Tamoanchan y Tlalocan. México, FCE, 1994 [2011].

López Austin, Alfredo, El pasado indígena. México, El Colegio de México, FHA y FCE, 2001.

López Austin, Alfredo, Monte sagrado. Templo Mayor. México, INAH, UNAM, IIA, 2009 [2011].

López Austin, Alfredo, Cuerpo humano e ideología. México, UNAM, IIA, 2012.

López Austin, Alfredo, Las razones del mito Dios. México, Era, 2015.
López de Cogolludo, fray Diego, Historia de Yucatán. Mérida, Imp. de Manuel Aldana Rivas, 1867.

Lumholtz, Carl, Unknown Mexico. Nueva York, Charles Schibner's Sons, 1902.

Lumholtz, Carl, "The Huichol Indians of Mexico", Bulletin of the American Museum of Natural History, X (1898), 1-14.

Madsen, William, Christo Paganism. A Study of Mexican Religious Syncretism. Nueva Orleáns, Middle American Research Institute, Tulane University, 1957.

Manzanilla, Linda y López Luján, Historia antigua de México. México, UNAM, IIA, 1995 [2014].

Martí, Samuel, Instrumentos musicales precortesianos. México, INAH, 1955.

Martí, Samuel, Canto, danza y música precortesianos. México, Fondo de Cultura Económica, 1961.

Marroquín Narváez, Graciela Mirna, Aspectos generales de la música prehispánica percibidos a través de sus imágenes. Tesis de Maestría en Educación por el Arte, Monterrey (México), Universidad Autónoma de Nuevo León, Facultad de Artes Visuales, 2004.

Matos Moctezuma, Eduardo, Vida y muerte en el Templo Mayor. México, FCE, 1986 [2013].

Mendieta, fray Gerónimo, Historia eclesiástica indiana. (García Icazbalceta, Joaquín, ed.). México, Antigua Librería, 1870. [México, CONACULTA, 1997].

Méndez, Alejandro y Agustín Pimentel, Tipología de instrumentos arqueológicos en Mesoamérica. Tesis de Arqueología, México, ENAH, 2006.

Mendoza, Vicente T., "Música Precolombina de América", Boletín Latinoamericano de Música, IV (1938), 244-247.

Mendoza, Vicente T., "Tres instrumentos musicales prehispánicos", Anales del Instituto de Investigaciones Estéticas, VII (1941), 71-86.

Mendoza, Vicente T., "Música Indígena de México", México en el Arte, IX (1950), 58-62.

Merriam, Alan P., Panorama de la música tradicional de México. México, UNAM, 1956.

Merriam, Alan P.; and Acevedo, Warren L. d', "Washo Peyote Songs", American Anthropologist, 59/4 (August, 1957), 615-641.

Merriam, Alan P., The Anthropology of Music. Chicago, Northwestern University Press, 1964 [1971].

Molina, Alonso de, Arte de la lengua mexicana y castellana. México, Pedro de Ocharte, 1571 [2 $2^{\mathrm{a}}$ impresión corregida, México, Pedro Balli, 1576, reimpr. en México, Anales del Museo Nacional de México, IV/1 (1886); reimpr. facsímil, Madrid, Ed. Cultura Hispánica, col. "Incunables Americanos del Siglo XVI, v", 1945].

Molina, Alonso de, Vocabulario en lengua castellana y mexicana. México, Antonio de Espinosa, 1571 [ed. facsimilar, Madrid, Ediciones Cultura Hispánica, 1944; México, Porrúa, 2001].

Motolinía, fray Toribio de Benavente, Memoriales e historia de los indios de la Nueva España. Madrid, Atlas, IV, 1970. 
Motolinía, fray Toribio de Benavente, Memoriales o libro de las cosas de la Nueva España. México, UNAM, IIH, 1971.

Nettl, Bruno, Theory and Method in Ethnomusicology. LondresNueva York, Free Press of Glencoe, 1964.

Ochoa Cabrera, José Antonio; y Cortés Hernández Claudia, $\mathrm{Ca}$ tálogo de instrumentos musicales y objetos sonoros del México indígena. México, FONCA, 2002.

Oliver, Guilhem, Tezcatlipoca. Burlas y metamorphosis de un dios Azteca. México, FCE, 1997 [2004].

Oliver, Guilhem, "Huehuecóyotl, «Coyote Viejo», el músico transgressor. ¿Dios de los otomíes o avatar de Tezcatlipoca?", Estudios de Cultura Náhuatl, 30. México, UNAM, IIH, 1999.

Olmos, Fray Andrés de, Arte de la lengua mexicana. México, UNAM, IIH, 1993 [2002].

Olsen, Dale A., "The ethnomusicology in music archaeology", (De Vale, Sue Carole, ed.) Selected reports in Ethnomusicology, 8 ["Issues in organology"] (1990), 175-197.

Orta Velázquez, Guillermo, Breve historia de la música en México. México, Porrúa, 1970.

Ortiz, Fernando, "Instrumentos musicales indoamericanos", Review of Interamerican bibliography, VII/4 (Octubre, 1957), 381-387.

Pedelty, Mark Holmes, Musical Ritual in Mexico City, from the Aztecs to Nafta. Austin, University of Texas Press, 2004.

Pimentel Díaz, Ángel Agustín; et al., "La música y los instrumentos musicales antiguos", Historia del arte de Oaxaca: 1. Arte prehispánico. Oaxaca, Instituto Oaxaqueño de las culturas, 1997.

Fuente, Beatriz de la (coord.), La Pintura Mural Prehispánica en México. México, CONACULTA, Jaca Book, UNAM, IIE, 1999.

Raby, Dominique, "Xochiquetzal en el cuicacalli, cantos de amor y voces femeninas entre los antiguos nahuas", Estudios de Cultura Náhuatl, vol. 30. México, UNAM, 1999.

Recinos, Adrián (ed.), Popol Vuh. Las Antiguas Historias del Quiche. México, FCE, 1947.

Reuter, Jas, Los instrumentos musicales en México. México, Fondo Nacional para el fomento de las artesanías, FNAS, 1982.

Ribera, Roberto, Los instrumentos musicales de los mayas. México, SEP, INAH, 1980.

Ricard, Robert, La conquista espiritual de México. México, FCE, 1947 [2013].

Robelo, Cecilio A., Diccionario de la Mitología Náhuatl. México, Ediciones Fuente Cultural, Librería Navarro, 1951.

Robelo, Cecilio A., Diccionario de Aztequismos. México, Ediciones Fuente Cultural, 1948.

Rodríguez, Ignacio, "Instrumentos musicales de México", Suplemento del diario Excélsior, México, 4 de diciembre, 1966.

Romero, Jesús C., Mística precortesiana. México, Ed. Stylo, 1947.

Romero Quiroz, Javier, El huéhuetl de Malinalco. Toluca, UNAM, 1958.

Romero Quiroz, Javier, El teponaztli de Malinalco. Toluca, UNAM, 1964.
Sachs, Curt, Geist und Werden der Musikinstrumente. Berlín, Dietrich Reimer, 1929.

Sachs, Curt, The History of Musical Instruments. Nueva York, W. W. Norton, 1940 [1968].

Sachs, Curt, Historia de los instrumentos musicales. Buenos Aires, Centurión, 1944.

Sachs, Curt, Real-lexicon der Musikinstrumenten. Hildesheim, Olms, 1964.

Sahagún, fray Bernardino de, Manuscrito de la Biblioteca de Palacio. XXX, XXX, XXX.

Sahagún, fray Bernardino de, Historia General de las Cosas de Nueva España. (Garibay Kintana, Ángel María, ed.). México, Porrúa, 1956.

Sahagún, fray Bernardino de, Historia general de las cosas de Nueva España, Códice Florentino. (García, Josefina; y López Austin, Alfredo, eds.). 2 vols. México, Fomento Cultural Banamex, 1982.

Sahagún, fray Bernardino de, Primeros memoriales. (Sullivan, Thelma (traduc. del náhuatl y ed. en inglés). 2 vols. Norman, University of Oklahoma Press, 1997.

Saldívar, Gabriel, Historia de la música en México. México, SEP-INBA, Ed. Cultura, 1934.

Séguy, Marie-Rose; et Simoni-Abbat, Mireille (dirs.), Aztlán, Terre des Aztèques. Images d'un nouveau monde. París, Bibliothèque Nationale, 1976.

Séjourné, Laurette, El universo de Quetzalcóatl. México, FCE, 1962 [2013].

Séjourné, Laurette, El pensamiento náhuatl cifrado por los calendarios. México, Siglo XXI, 1981 [2009].

Seler, Eduard Georg, "Mittelamerikanische Musikinstrumente [Instrumentos musicales centroamericanos]“, Globus, 76 (1899), 109-112; \& "II" (1904), 695-703.

Seler, Eduard Georg, "Altmexicanischen Knochenrasseln [Sonajas de hueso de los antiguos mexicanos]", Globus, 74 (1898), 85-93; \& “II" (1904), 672-694.

Seler, Eduard Georg, "Die Holzgeschnitzte Pauke von Malinalco und das Zeichen atl-tlachinolli", Mitteilungen der Anthropologischen Gesellschaft in Wien, 34 (1904), 222-274.

Seler, Eduard Georg, Las imágenes de animales en los manuscritos mexicanos y mayas. (1909-1910). México, Casa Juan Pablos, 2008.

Seler, Eduard Georg, Gesamelte Abhandlungen zur amerikanischen Sprach und Altertunskunde. Berlín, Behrend und Co., 1923 [Graz, XXX, 1960].

Seler, Eduard Georg, Comentarios al Códice Borgia. 2 vols. México, FCE, 1963.

Seler, Eduard Georg, Los cantos religiosos de los antiguos mexicanos. Partes I y II. México, UNAM, "Estudios de Cultura Náhuatl, vols. 47-48”, 2014.

Simeón, Remi, Diccionario de la lengua náhuatl o mexicana. (1885). México, Siglo XXI eds., 1977.

Soustelle, Jacques, La vida cotidiana de los aztecas en vísperas de la conquista. México, FCE, 1955 [2013].

Soustelle, Jacques, El universo de los aztecas. México, FCE, 1979 [2013].

ANUARIO MUSICAL, N. ${ }^{\circ}$ 73, enero-diciembre 2018, 37-52. ISSN: 0211-3538 doi:10.3989/anuariomusical.2018.73.03 
Stevenson, Robert, Music in Aztec and Inca Territory. Los Ángeles, UCLA Press, 1971.

Stevenson, Robert, Crónica Mexicáyotl. (León, Adrián, trad. del náhuatl). México, IIH, UNAM, 1995.

Stevenson, Robert, "Reflexiones sobre el concepto de música precortesiana en México", Heterofonía: Revista musical, 114-115 (ene-dic. 1996), XXX-XXX.

Tezozomoc, Hernando Alvarado, Crónica mexicana. México, M. Orozco y Berra, 1878.

Thomson, Erick, Maya hieroglyphic writing. Norman, University of Oklahoma Press, 1960.

Torquemada, fray Juan de, Monarquía Indiana. México, UNAM, 1975.

Turrent, Lourdes, La conquista musical de México. México, FCE, 1993 [2006].

Vega, Alejandro, Instrumentos musicales, vírgulas del sonido y danza en cerámica, pintura y códices prehispánicos. Base de datos digital con imágenes y bibliografía comentada. Informe académico de servicio social para titulación de Licenciado en Historia, México, Facultad de Filosofía y Letras, Colegio de Historia, 2013.

Weiant, C. W., An Introduction of the Ceramics of Tres Zapotes. Washington D.C., Goverment Printing Office, "Ethnology Bulletin, 139", 1943.

Yáñez, Agustín, Mitos Indígenas. México, UNAM, 1942 [1991].

\section{Códices consultados en original o en facsímil:}

Antigüedades de México: los códices reproducidos en esta publicación basada en la recopilación de lord Edward King Kingsborough (1831) cuentan con un estudio e interpretación de José Corona Núñez Núñez, 3 vols. México, Secretaría de Hacienda y Crédito Público, 1964. Se consultaron en esta fuente los siguientes:

Volumen I:

Códice Mendocino o Colección Mendoza.

Códice Telleriano Remensis.

Volumen II:

Códice Boturini o Tira de la Peregrinación.

Códice Bodley.

Códices Selden I y II.

Volumen III:

Códice Vaticano-Rios.

Códice Laud.

Otras Fuentes:

Códice Azcatitlán. (Graulich, Michel; y Barlow, Robert H., eds.; y López Luján, Leonardo, trad.). 2 vols. París, Bibliothèque Nationale de France, 1995. [Facsímil].

Códice Bodley 2858. Facsímil en: Caso, Alfonso, The Interpretation of the Codex Bodley 2858. México, Sociedad Mexicana de Antropología, 1960.
Códice Borbónico. (Paso y Troncoso, Francisco del, ed.). Facsímil. México, Siglo xxI, 1979.

Códice Borbónico. (Anders, Ferdinand; et al., eds.). México, FCE, Akademische Druck und Verlagsanstalt, Sociedad Estatal Quinto Centenario, 1991.

Códice Borgia. (Anders, Ferdinand; et al., eds.). México, FCE, 1993.

Códice Borgia, (Anders, Ferdinand; et al., eds.). México, FCE, 1993.

Códice Borgia, (Ojeda Díaz, María de los Ángeles; et al., eds.). México, INAH, 1994.

Códice Chimalpopoca: Anales de Cuauhtitlán y Leyenda de los Soles. (Feliciano V., Primo, trad.). México, UNAM, Instituto de Historia, 1945 [México, IIH, 1992].

Códice Dresden. (Thompson, J. Eric S., ed.). México, FCE, 1988.

Códice Dresden. (Rosell, Cecilia; et al., eds.). México, INAH, 1994.

Códice Durán. (Gutiérrez, Electra; y Gutiérrez, Tonatiuh, eds.). México, Arrendadora internacional, 1990.

Códice Fejérváry-Mayer. (Anders, Ferdinand; et al., eds.). México, FCE, Akademische Druck-und-Verlagsanstalt, 1994.

Códice Florentino., en Sahagún (1982).

Códice Florentino. Facsímil. México, FCE, 1988.

Florentine Codex. (Anderson, Arthur J. O.; y Dibble, Charles E., eds. del texto original náhuatl y trad. al inglés). Santa Fe, Nuevo México, School of the American Research and the university of Utah, Monographs of the School of American Research and the Museum of New Mexico, 1959.

Códice Franciscano. (García Icazbalceta, Joaquín, ed.). México, Imp. Díaz de León, 1889.

Códice Franciscano. México, Chávez Hayhoe, 1941.

Códice Ixtlixóchitl. (Doesburg, Geert Bastian van, ed.). México, FCE, Akademische Druck-und-Verlangsanstalt, 1996.

Códice Magliabechiano. (Anders, Ferdinand; et al., eds.). México, FCE, Akademische Druck-und-Verlagsanstalt, 1994.

Códice de Madrid. (Sotelo Santos, Laura Elena, ed.). México, CONACULTA, 1998.

Códice Mendocino. (Mohar Betancourt, Luz María, ed.). México, INAH, 1996.

Códice Nutall. México, FCE, 1992.

Códice Tudela. Madrid, ICI, 1980.

Códice Vindobonensis. (Anders, Ferdinand; et al., eds.). México, FCE, Akademische Druck-und-Verlagsanstalt, 1992.

Códice Zouche-Nutall. (Anders, Ferdinand; et al., eds.). México, FCE, Akademische Druck-und-Verlagsanstalt, 1992.

Matrícula de Tributos (Códice Moctezuma). (Anders, Ferdinand; et al., eds.). México, FCE, 1997.

Tonalámatl de Aubin. México, Secretaría de Fomento, 1902.

Tonalámatl de Aubin. México, Ed. Innovación, 1979.

INTERNET: http://www.Codices.inah.gob.mx/pc/index.php (Recurso virtual con 48 códices de los siglos XVI, XVII, XVIII y XIX. Visitado el 29.11.2017). 